\title{
ЧЕЛОВЕЧЕСКИЙ КАПИТАЛ ИНВАЛИДА: ТРУДОВАЯ РЕАБИЛИТАЦИЯ И МЕТОДЫ ЕЁ ОЦЕНКИ
}

\author{
(C) 2019 Фадин Никита Игоревич \\ соискатель ФГБУ «ВНИИ труда» Минтруда России, Москва \\ E-mail: fadin-nikita@mail.ru
}

Цель данной статьи - определение факторов, влияющих на формирование и развитие трудового потенциала инвалида в составе компонентов человеческого капитала, выявление потребностей в расширении инвестиций в человеческий капитал инвалидов, роль государства и бизнеса в этом процессе. Проведен обзор зарубежных и отечественных исследований в области определения компонентов, элементов содержания человеческого капитала, обоснована необходимость его дополнения специфическими элементами становления и развития человеческого капитала у трудоспособных инвалидов. Уточнено содержание понятия «трудовая реабилитация инвалидов», как комплекса реабилитационных мероприятий с определением его составляющих по восстановлению способностей к трудовой деятельности и помощи в реализации профессиональных компетенций. Разработаны матрицы и формулы оценки трудового потенциала инвалидов с учетом их мотивации и поведения, а также формула интегрального показателя использования компетенций инвалида, раскрывающих их человеческий потенциал. Предложены организационно-административные мероприятия в виде: разработки и утверждения «Общероссийского гарантированного стандарта (регламента) реабилитационных мер по нозологии заболеваний приводящих к инвалидизации»; пилотных проектов: по созданию государственного учреждения «Агентства занятости инвалидов»; введения «Персональной интерактивной дорожной карты занятости инвалида»; нового формата взаимодействия с работодателями в формате «инклюзивного аудита» - для целей эффективной трудовой реабилитации инвалидов, создания рабочих мест, дальнейшего развития рынка труда для них, включая гибкие формы занятости.

Ключевые слова: инвалиды, лица с ограниченными возможностями, человеческий капитал инвалидов, трудовая реабилитация, рынок труда, занятость, агентство занятости инвалидов, трудовой потенциал инвалидов, мотивация, компетенции, инклюзивный аудит, дорожная карта занятости инвалидов.

В современном мире общепризнано, что одним из главных факторов, влияющих на развитие общества и его социально-экономическое состояние, является человеческий капитал. Он оценивается, в т.ч. в России, как национальное богатство страны и как основная движущая сила в ориентации на новый вектор развития экономики- экономики инновационной, цифровой, построенной на использование глобальных информационных систем, новейших технологий. Произошла переоценка значимости человеческого капитала: от затратной на производительную и социальную.

С ориентиром на развитие человеческого капитала строился предпочтительный сценарий в Концепции долгосрочного социально-экономического развития (КДР) Российской Федерации до 2020 - Стратегия 2020, включая раздел III «Новая социальная политика. Развитие человеческого капитала» (КДР утверждена в ноябре
2008 г.). Президент РФ В.В. Путин в своём послании Федеральному собранию в 2016 году отметил: «Смысл всей нашей политики - это сбережение людей, умножение человеческого капитала как главного богатства России»... [19].

В национальном богатстве развитых стран человеческий капитал колеблется от 70 до $80 \%$. У России в 2018 г. он оценен в 73\% [10]. По данным Всемирного банка, Россия занимает 34-е место из 157 и входит в группу стран с высоким уровнем человеческого капитала [18].

О не снижающийся актуальности темы развития человеческого капитала, также свидетельствует её обсуждение на международном форуме труда, проходившим в Санкт-Петербурге, в 2019 г. На пленарном заседании дискутировался вопрос: «Человеческий капитал и труд будущего» [10].

В контексте темы исследования, были проанализированы многочисленные источники, за- 
трагивающие проблемы становления и развития человеческого капитала, с поиском дифференцированных подходов к отдельным социальным группам и, в частности, к трудоспособным инвалидам.

Общеустановлено, что основоположниками современной теории человеческого капитала являются лауреаты Нобелевской премии 1979 и 1992 гг. соответственно Т. Шульц и Г. Беккер американские ученые-экономисты.

Первое определение человеческого капитала принадлежит Т. Шульцу.

В своей работе «Инвестиции в человеческий капитал» он писал: «Концепция капитала исходит из наличия нечто реально существующего, что обладает экономическим свойством оказывать будущие услуги, имеющие некоторую стоимость. Понимание капитала, как нечто такого, что оказывает будущие услуги, позволяет приступить к последующему делению целого на две части: на человеческий и нечеловеческий капитал» [32].

Т. Шульц рассматривал человеческий капитал, через призму составляющих его и неотделимых компонентов: человеческий капитал - как дополнительный источник дохода; образование - как одна из форм капитала, обеспечивающая экономический рост и источник заработков; инвестирование в образование как одно из вложений средств в факторы производства, со3дающие прибавочный продукт [33-34].

Г. Беккер внёс большой вклад в данное научное направление и считается общепризнанным создателем научной школы в рамках концепции человеческого капитала. В книге «Инвестиции в человеческий капитал», изданной в 1962 году, Гэри Беккер писал, что человеческий капитал формируется за счет инвестиций в человека: обучение, подготовку на производстве, расходы на здравоохранение, миграцию, поиски информации о ценах и доходах. Он рассматривал человеческий капитал в единстве с его обладателем - работником, базирующимся на запасе его знаний и приносящим прирост дохода в процессе трудовой деятельности [2-3] [4] [35-36].

Определенный вклад в расширение трактовки теории человеческого капитала внесли советские ученые: В.И. Басов, В.С. Гойло, А.В. Дайновский, Р.И. Капелюшников, В.В. Кафидов, В.П. Корчагин, В.В. Клочков, В.И. Марцинкевич. Так, например, Р.И. Капелюшников считает, что человеческий капитал - это определенный запас знаний, способностей и мотиваций, которые присущи определенному человеку. С одной стороны, они требуют отвлечения средств в ущерб текущему потреблению, а с другой - являются надежными источниками заработков и доходов в будущем [15].

В современной российской науке теорией человеческого капитала фундаментально начали заниматься только с начала девяностых годов прошлого столетия, т.е. одновременно с началом экономических реформ в России. В этот период появились работы в данной области С.А. Дятлова, А.И. Добрынина, И.В. Ильинского, Р.И. Капелюшникова, М.М. Критского, В.Т. Марцинкевича.

В научном сообществе принято использовать следующую классификацию человеческого капитала:

- Индивидуальный человеческий капитал.

- Человеческий капитал фирмы.

- Национальный человеческий капитал [16].

Применительно к предмету нашего рассмотрения - человеческого капитала инвалида, к сожалению, приходится констатировать практическое отсутствие исследований в данном направлении. Однако необходимо сделать важное уточнение: приносить доход государству и себе способны лишь инвалиды в трудоспособном возрасте, в случае выдачи им трудовой рекомендации бюро медико-социальной экспертизы [26]. В тоже время, по численности это весьма ощутимый трудовой потенциал: в масштабе России 2,2 млн. чел., в Москве - 138 тыс. чел. [23] [27].

В современном экономическом словаре в определении теории человеческого капитала, отмечено, что человеческий капитал может уменьшаться под воздействием морального или физического износа и увеличиваться в зависимости от инвестирования [5].

Действительно, наступление инвалидности в трудоспособном возрасте - это своего рода констатация физического, физиологического износа, иначе говоря - износа здоровья.

«Инвалид - лицо, которое имеет нарушение здоровья со стойким расстройством функций организма, обусловленное заболеваниями, последствиями травм или дефектами, приводящее к ограничению жизнедеятельности и вызывающее необходимость его социальной защиты...» [26].

В последние годы в речевых оборотах, в различных информационных и официальных источниках, в научных работах и пр. используется синонимичное тождество понятий «инва- 
лид» и «лицо с ограниченными возможностями здоровья». На наш взгляд такие аналогии весьма спорны, в виду того, что понятие «инвалид» в России установлено законом, оно также является официальным в Международных документах, например, в Конвенции ООН «О правах инвалидов». Что касается американизированной терминологии: «Лицо с ограниченными возможностями», «Лицо с ограниченными возможностями здоровья» и пр., то она отражает попытку общества, подходить к определению субъекта нашего исследования с толерантной точки зрения, не вызывая тем самым дискриминации [24].

По этому поводу идут различные дискуссии. Однако среди самих инвалидов немало негативных эмоций относительно их классификации как «лиц с ограниченными возможностями». Действительно мы являемся свидетелями того, что среди них есть люди, обладающие талантами в различных сферах искусства, техники, в других науках, т.е. высоким человеческим капиталом. А достижения спортсменов с физическими недостатками порой превосходят результаты здоровых людей.

Рассматривая процессы, связанные с восстановлением человеческого капитала инвалидов трудоспособного возраста и инвестиции необходимые для этого, правильнее ориентироваться на разностороннее понимание человеческого капитала, сформулированное Т.Шульцем: «Все человеческие способности являются или врожденными, или приобретенными. Каждый человек рождается с индивидуальным комплексом генов, определяющим его врожденные способности. Приобретенные человеком ценные качества, которые могут быть усилены соответствующими вложениями, мы называем человеческим капиталом» [32].

Основным гарантом, обладающим возможностью обеспечить вложения (инвестиции) в развития ценных качеств у инвалида и сформировать для этих целей необходимый реабилитационный механизм, является государство. Это обоюдный интерес, поскольку неработающий человек не влияет на экономический рост в обществе, а качество его жизни резко снижается, для поддержания которого необходимы меры социальной защиты, т.е. затраты государства [14].

Данные факторы, а также соблюдение конституционных гарантий как социального государства, ратификация Конвенции о правах инвалидов, накладывают на федеральные и региональные органы власти обязанность осу- ществлять действенные меры по формированию и развитию человеческого капитала инвалидов. При этом, следует иметь ввиду, что каждой компоненте человеческого капитала соответствует свой вид инвестиций [12-13].

В целом для населения принято выделять три основных направления инвестиций:

- расходы на образование,

- расходы на здравоохранение,

- расходы на мобильность.

У инвалидов потребность в инвестициях шире и по удельному весу вложений, и по направлениям:

- расходы на реабилитацию (медицинскую, психологическую, социально-средовую);

- расходы на формирование доступной среды;

- расходы на создание адаптированных и специализированных рабочих мест;

- расходы на заработную плату трудового куратора.

Чтобы идти в ногу со временем в направлении развития человеческого капитала инвалидов, следует иметь в виду, что основной мотив долгосрочной концепции России - это инновационное развитие и новое качество человеческого капитала с потенцией на обновление знаний, на переквалификацию или же при необходимости - смене профессии.

Именно в таком ключе должна осуществляться организация трудовой реабилитации инвалидов. В тоже время, на протяжении долгого периода времени научные исследования, посвящённые проблемам инвалидов в России, сводились к вопросам их социально-бытового обеспечения, предоставления социальных услуг и социокультурной реабилитации. Новые подходы в сфере профессиональной реабилитации инвалидов появились в работах Э.К.Наберушкиной, Н.Н. Малофеева, Д.Б. Шевченко, П.В. Романова, А.А. Чернецкой и др. А в трудах С.А. Жилина, М.Ю. Погудаевой, .Г. Карпова, О.В.Новожиловой и др., отражены исследования зарубежного опыта по использования труда инвалидов.

Одними из жизненно важных социально-экономических гарантий для инвалидов трудоспособного возраста со стороны государства являются гарантии предоставления максимально возможного восстановления и последующего сохранения здоровья, а также возможности социализации, включая занятость. В этих целях в России принят необходимый пакет норматив- 
но-правовых актов.

В целом методы и технологии восстановления и повышения трудоспособности инвалидов, а также особенности осуществления ими трудовой деятельности, неразрывно связаны с доступностью и качеством реабилитации и абилитации, являющихся компонентами, формирующими человеческий капитал инвалидов [28-29].

В соответствии с действующим законодательством:

«Реабилитация инвалидов - система и процесс полного или частичного восстановления способностей инвалидов к бытовой, общественной, профессиональной и иной деятельности. Абилитация инвалидов - система и процесс формирования отсутствовавших у инвалидов способностей к бытовой, общественной, профессиональной и иной деятельности. Реабилитация и абилитация инвалидов направлены на устранение или возможно более полную компенсацию ограничений жизнедеятельности инвалидов в целях их социальной адаптации, включая достижение ими материальной независимости и интеграцию в общество.

Основные направления реабилитации и абилитации инвалидов включают в себя: медицинскую реабилитацию, реконструктивную хирургию, протезирование и ортезирование, санаторно-курортное лечение; профессиональную ориентацию, общее и профессиональное образование, профессиональное обучение, содействие в трудоустройстве (в том числе на специальных рабочих местах), производственную адаптацию; социально-средовую, социально-педагогическую, социально-психологическую и социокультурную реабилитацию, социально-бытовую адаптацию; ф физкультурно-оздоровительные мероприятия, спорт.» [26].

Соответственно, для поддержания и восстановления трудоспособности инвалидов необходимы инвестиции на постоянную или периодическую медицинскую помощь, на комплекс других в т.ч. инновационных реабилитационных услуг. В противном случае, весьма проблематично восстановить трудовой потенциал в составе человеческого капитала инвалида, т.е. в отношении инвалидов трудоспособного возраста должна осуществляться трудовая реабилитация [22].

Проведенный автором анализ существующей теории и практики показал, что в настоящее время в определении содержания трудовой реабилитации различными исследователями включаются отдельные, разрозненные, обособленные компоненты, которые рассматриваются преимущественно в составе профессиональной реабилитации, в т.ч. без учета компонентов содействия занятости инвалидов (см. рис. 1).

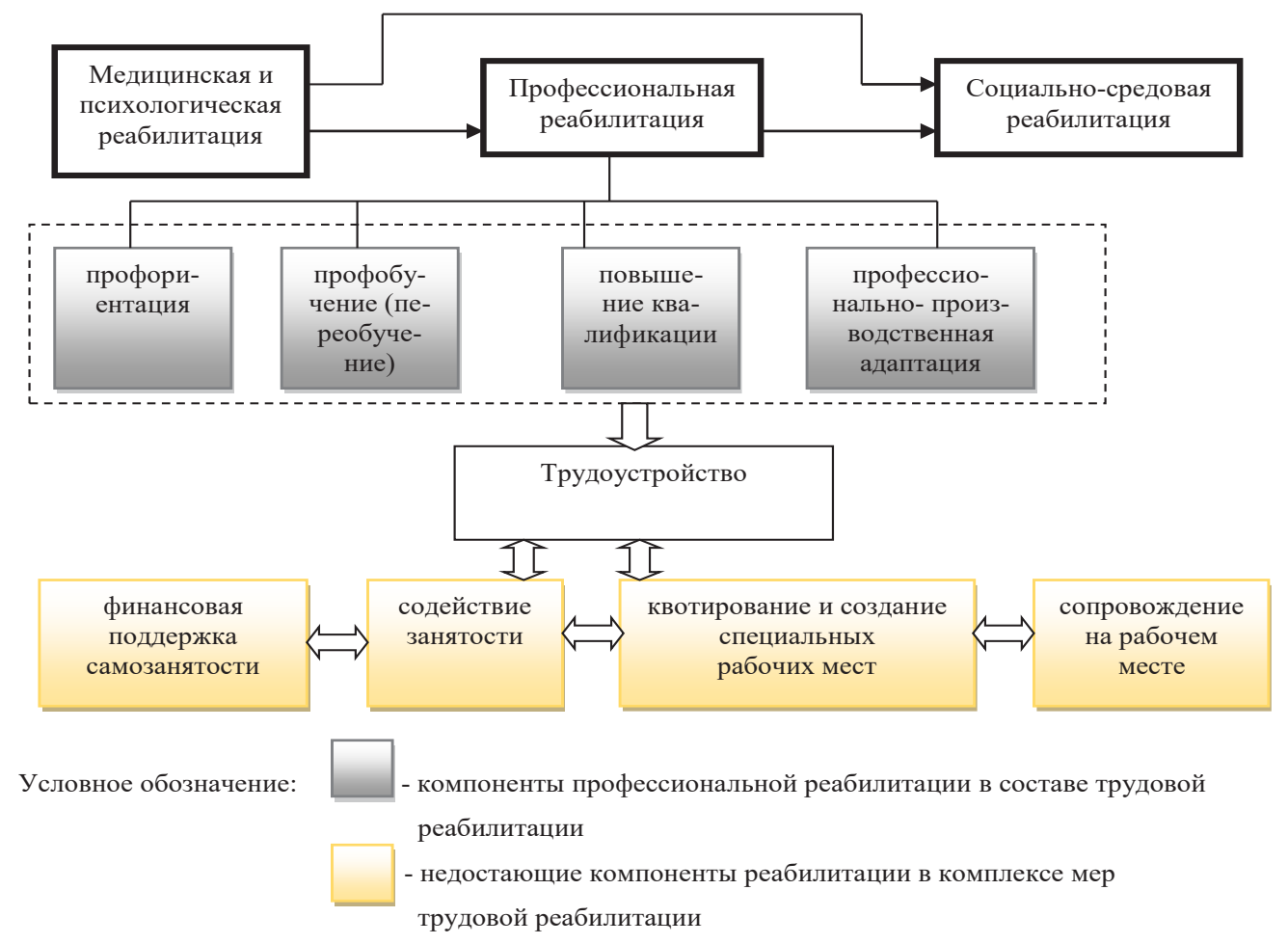

Puc. 1. Комплекс компонентов трудовой реабилитации как механизм формирования человеческого капитала инвалидов.

Источник: Разработано автором 
Целью трудовой реабилитации инвалида, в исчерпывающем понимании содержании этого термина, должна стать не только его комплексная подготовка к осуществлению трудовой деятельности (в т.ч. конкурентоспособность на рынке труда), а также содействие в трудоустройстве и закреплении на рабочем месте. Такая постановка задачи имеет высокую социально-экономическую значимость в жизни трудоспособных инвалидов и требует серьезных консолидированных мер со стороны органов власти и бизнеca [1].

В первую очередь, по мнению автора, для оказания инвалидам более качественного и исчерпывающего пакета реабилитационных услуг крайне необходима разработка и утверждение общероссийского гарантированного стандарта (регламента) реабилитационных мер, с учетом нозологии по заболеваниям, приводящим к инвалидизации (онкология; системы кровообращения; опорно-двигательного аппарата; нарушений обменных процессов; систем дыхания и пищеварения; нервно - психического состояния; органов чувств, т.ч. слуха, зрения и т.д.). Наличие таких стандартов поможет соответствующим отраслевым органам власти дифференцированно обеспечивать реабилитационные службы необходимым штатом специалистов и советующими технических средствами реабилитации. В рамках этих стандартов инвалид смог бы гарантированно получать весь комплекс реабилитационных мероприятий, включая содействие занятости и перейти в состав экономически активного населения [8-9] [11] [20].

Предложенный подход к совершенствованию процесса накопления человеческого капитала инвалида, оптимизирует инвестиции в его реабилитацию, сроки их предоставления и как следствие сроки возврата инвестиций.

Действующий с 1 апреля 2013 года «Реабилитация инвалидов. Услуги по социальной реабилитации инвалидов. ГОСТ Р 54738-2011» предусматривает лишь перечень основных видов реабилитационных услуг по социальной реабилитации, включающих в себя: социальной-средовую, социально-психологическую, и социокультурную реабилитации; социально-бытовую адаптацию без дифференциации: по возрастным группам, по показаниям к трудовой деятельности и прочим составляющим [6].

Вполне естественно, что трудовая реабилитация инвалидов не возможна без профес- сиональной ориентации, профессиональной подготовки, переподготовки, самоподготовки, самообучения, оказания помощи в подборе работы и трудоустройстве, организации производства, организации труда, процесса труда, организации рабочего места, нормирования труда, оплаты и стимулирования труда и т.д.

Вместе с тем, нельзя не учитывать такой важный аспект, как потребности самого инвалида, особенности мотивационного механизма формирования и накопления человеческого капитала (потенциала).

Если в традиционной формулировке потребности человека формируются от физиологических до самореализации через социализацию, то для лиц с ограниченными возможностями здоровья социализация часто остается высшим уровнем потребностей (см. рис. 2).

Потребности самореализации и самосовершенствования возникают и реализуются в результате использования инвалидом своего интеллектуального потенциала.

В целом социально-экономическая особенность формирования и развития человеческого капитала инвалидов связана с качеством организации трудовой реабилитации в данном субъекте страны, наличием рынка труда для инвалидов, в связи с чем важная роль на завершающих этапах трудовой реабилитации отводится службам занятости [25]. На этапе первого собеседования с инвалидом, службе занятости, следует:

1) установить имел ли инвалид профессию на момент выдачи ему бюро МСЭ трудовой рекомендации, если не имел, то с учетом рекомендаций в ИПРА совместно с инвалидом определиться какими видами труда он хотел бы заниматься и сможет ли он продолжить работу в прежней должности;

2) при желании инвалида и необходимости сменить профиль профессиональной подготовки или приобрести новую профессию направить его на обучение/переобучение. При отказе от обучения разъяснить о возможности трудоустройства только на низкоквалифицированные виды труда;

3) после окончания обучения оказать содействие в трудоустройстве на вакантную должность или на квотируемое рабочее место, решив с работодателем вопросы обустройства рабочего места, необходимости предоставления услуг трудового куратора.

Помочь в процессе трудоустройства и уста- 


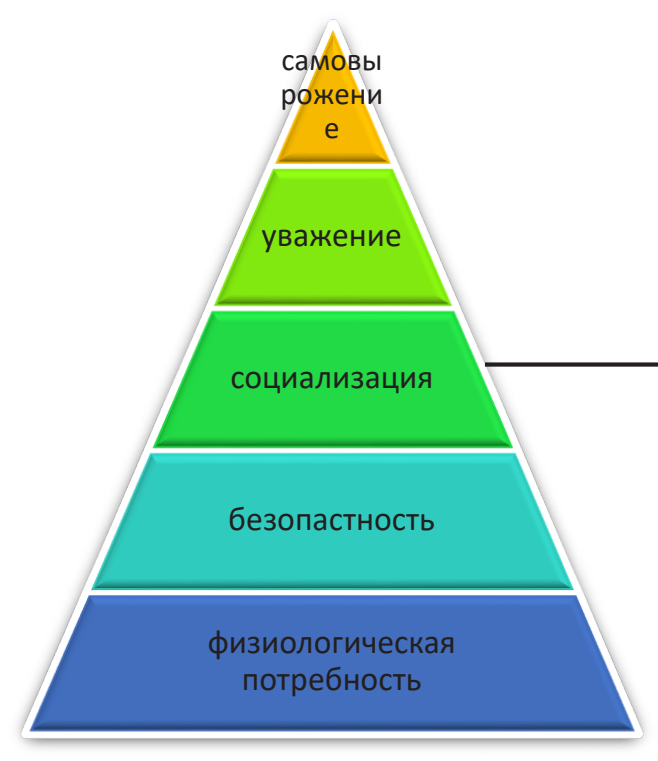

Иерархия потребностей человека по А. Маслоу

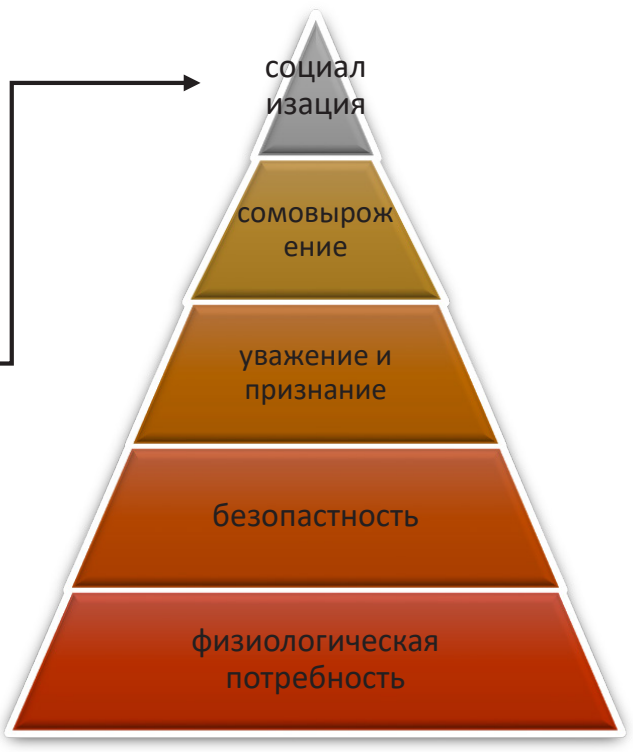

Иерархия потребностей (инвалидов) лиц с ограниченными возможностями здоровья

Рис.2. Трансформация иерархии потребностей инвалидов Источник: Переработано и дополнено автором

новления обратной связи с работодателем, поможет, разработанная автором (см. табл. 1). Матрица общей оценки соответствия элементов профессиональной компетенции инвалида к требованиям должности.

Сведения, содержащаяся в матрице (табл. 1) помогут не только службе занятости в подборе подходящей работы при трудоустройстве инвалида, сравнив его компетенции с требованиями работодателя, но и представителю работодателя полнее оценить потенциальные возможности инвалида, поскольку практически каждая из перечисленных компетенций влияет на успешность выполнения производственных задач. Бланк «оценки» предлагается заполнять в 2-х экземплярах, один из которых выдавать на руки инвалиду для представления работодателю.

В процессе трудовой реабилитации участвует множество различных отраслевых и территориальных ведомств: здравоохранение, образование, социальная защита, занятость, префектуры, строительные и транспортные службы и т.д. Вместе с тем, в этой системе отсутствует единая служба, которая координировала бы деятельность всех структур, участвующих в организации трудовой реабилитации инвалидов.

В связи с чем, в целях эффективного реше- ния данного вопроса, совершенствования механизма содействия занятости инвалидов, по мнению автора целесообразно создание «Агентства занятости инвалидов» (далее - Агентство/АЗИ). Отработку пилотного проекта возложить на Департамент труда и социальной защиты населения города Москвы.

Агентство должно представляет собой форму концентрации ресурсов (кадровых, материально-технических, учебно-методических, информационных, финансовых и т.д.), в том числе, располагать средствами для финансирования научных и мониторинговых исследований, разработки научно-методических материалов.

Кроме того, Агентство в обязательном порядке наряду с отраслевыми и территориальными органами власти должно тесно взаимодействовать с работодателями на основе государственно-частного партнерства, с общественными организациями инвалидов для целей эффективной трудовой реабилитации инвалидов и создания рабочих мест [7].

Одновременно, для успешного решения задач по трудовой реабилитации инвалидов, т.е. инвалидов, имеющих трудовые рекомендации, было бы целесообразно использовать опыт Германии, в части постоянного сопровождения это- 
Таблица 1. Матрица оценки соответствия элементов профессиональной компетенции инвалида к требованиям вакантной должности

\begin{tabular}{|c|c|c|c|c|c|c|}
\hline \multirow[t]{2}{*}{ № } & \multirow[t]{2}{*}{$\begin{array}{c}\text { Компетентностный портрет } \\
\text { инвалида }\end{array}$} & \multirow{2}{*}{$\begin{array}{l}\text { Требо- } \\
\text { вания к } \\
\text { профес- } \\
\text { сии } \\
*\end{array}$} & \multicolumn{2}{|c|}{$\begin{array}{c}\text { Наличие или отсут- } \\
\text { ствие элементов } \\
\text { компетенции } \\
* *\end{array}$} & \multirow{2}{*}{$\begin{array}{l}\text { Необходи- } \\
\text { мые ком- } \\
\text { петенции } \\
\text { для вы- } \\
\text { полнения } \\
\text { работы }\end{array}$} & \multirow{2}{*}{$\begin{array}{c}\text { Специальные } \\
\text { требования } \\
\text { работодателя по } \\
\text { вакантной долж- } \\
\underset{\text { ности }}{* \%} \\
\end{array}$} \\
\hline & & & $\ll+»$ & $\ll-»$ & & \\
\hline 1 & $\begin{array}{l}\text { Образование } \\
\text { - доктор наук } \\
\text { - кандидат наук } \\
\text { - специалист } \\
\text { - бакалавр } \\
\text { - магистр } \\
\text { - средне-профессиональное } \\
\text { - аттестат (полный) } \\
\text { - аттестат (средний) } \\
\text { - отсутствует }\end{array}$ & & & & & Образование \\
\hline 2 & $\begin{array}{l}\text { Квалификация } \\
\text { - разряд; } \\
\text { - категория; } \\
\text { - классный чин; }\end{array}$ & & & & & Квалификация \\
\hline 3 & $\begin{array}{l}\text { Практический опыт работы } \\
\text { - до } 1 \text { года; } \\
\text { - до } 3 \text { лет; } \\
\text { - более } 3 \text { лет; }\end{array}$ & & & & & $\begin{array}{l}\text { Практический } \\
\text { опыт работы }\end{array}$ \\
\hline 4 & $\begin{array}{l}\text { Прикладные знания } \\
\text { - опыт работы с программным } \\
\text { обеспечением; } \\
\text { - навыки программирования; } \\
\text { - и т.д. }\end{array}$ & & & & & $\begin{array}{l}\text { Прикладные } \\
\text { знания }\end{array}$ \\
\hline 5 & $\begin{array}{l}\text { Когнитивные навыки } \\
\text { - владение иностранным или } \\
\text { несколькими языками; }\end{array}$ & & & & & $\begin{array}{l}\text { Когнитивные } \\
\text { навыки }\end{array}$ \\
\hline 6 & $\begin{array}{l}\text { Дополнительные навыки } \\
\text { (с опытом/без опыта работы) } \\
\text { - вторая профессия; } \\
\text { - повышение квалификации; }\end{array}$ & & & & & $\begin{array}{c}\text { Дополнительные } \\
\text { навыки }\end{array}$ \\
\hline 7 & $\begin{array}{l}\text { Коммуникативные умения } \\
\text { - опыт работы в коллективе; } \\
\text { - опыт работы с населением; } \\
\text { - опыт ведения переговоров и } \\
\text { пр. }\end{array}$ & & & & & $\begin{array}{l}\text { Коммуникатив- } \\
\text { ные умения }\end{array}$ \\
\hline 8 & $\begin{array}{l}\text { Самостоятельность и автоно- } \\
\text { мия } \\
\text { - умения и навыки по самообра- } \\
\text { зовании }\end{array}$ & & & & & $\begin{array}{l}\text { Самостоятель- } \\
\text { ность и автоно- } \\
\text { мия }\end{array}$ \\
\hline 9 & $\begin{array}{l}\text { Функциональная грамотность } \\
\text { - умения, навыки адаптации во } \\
\text { внешней среде; }\end{array}$ & & & & & $\begin{array}{l}\text { Функциональная } \\
\text { грамотность }\end{array}$ \\
\hline 10 & $\begin{array}{l}\text { Инновационность } \\
\text { - умение адаптации в экономи- } \\
\text { ческом развитии науки и техно- } \\
\text { логиях; } \\
\text { - навыки генерации инноваци- } \\
\text { онных процессов и пр. }\end{array}$ & & & & & $\begin{array}{c}\text { Инновацион- } \\
\text { ность }\end{array}$ \\
\hline 11 & $\begin{array}{l}\text { Особые компетенции } \\
\text { - поощрения, награды по преды- } \\
\text { дущей трудовой деятельности; } \\
\text { - изобретения; } \\
\text { - патенты и пр. }\end{array}$ & & & & & $\begin{array}{l}\text { Особые компе- } \\
\text { тенции }\end{array}$ \\
\hline
\end{tabular}

Примечание: * - заполняется службой занятости населения, согласно справочнику профессий Минтруда России; ** - заполняется специалистом службы занятости; *** - указывается работодателем в запросе на вакантную должность. 
го процесса соответствующими специалистами (реабилитологи, психологи, кураторы служб занятости и др.). Для организации контроля полноты и своевременности предоставления реабилитационных услуг на протяжение всего их цикла автором предлагается ведение «Персональной интерактивной дорожной карты занятости инвалида» (далее Дорожная карта). Её первоначальное электронное составление (в дополнении к ИПРА), следует осуществлять в бюро МСЭ, с момента признания инвалида способным к трудовой деятельности. Учитывая, что сопровождать и заполнять Дорожную карту должны службы различных отраслевых органов власти, а также работодатели разработку окончательного формата бумажного и электронного носителя Дорожной карты, регламента её сопровождение и других организационно-технических вопросов целесообразно отработать на базе «Агентства», так же в режиме пилотного проекта, поскольку ДТСЗН г. Москвы располагает необходимой инфраструктурой, каналами связи (см. рис. 3).
В дорожной карте должен быть отражен весь комплекс социальных, медицинских, психологических и др. реабилитационных услуг, требующихся для восстановления человеческого капитала конкретного инвалида. В последствии, при необходимости будет нетрудно посчитать объем инвестиций, вложенных как в конкретного человека, так и в целом по региону. Заполнять Дорожную карту по мере предоставления реабилитационных услуг должны соответствующие учреждения, службы занятости, работодатель, а также сам инвалид с оценкой предоставленных услуг, используя для этого разработанную интерактивную информационную платформу.

Введение Дорожной карты инвалида позволит построить оптимальный маршрут его трудовой реабилитации, повысить вероятность стабильной трудовой деятельности, профессиональной самореализации и возможного карьерного роста.

К информационной базе данных Агентства, также будет необходимо подключить: реаби-

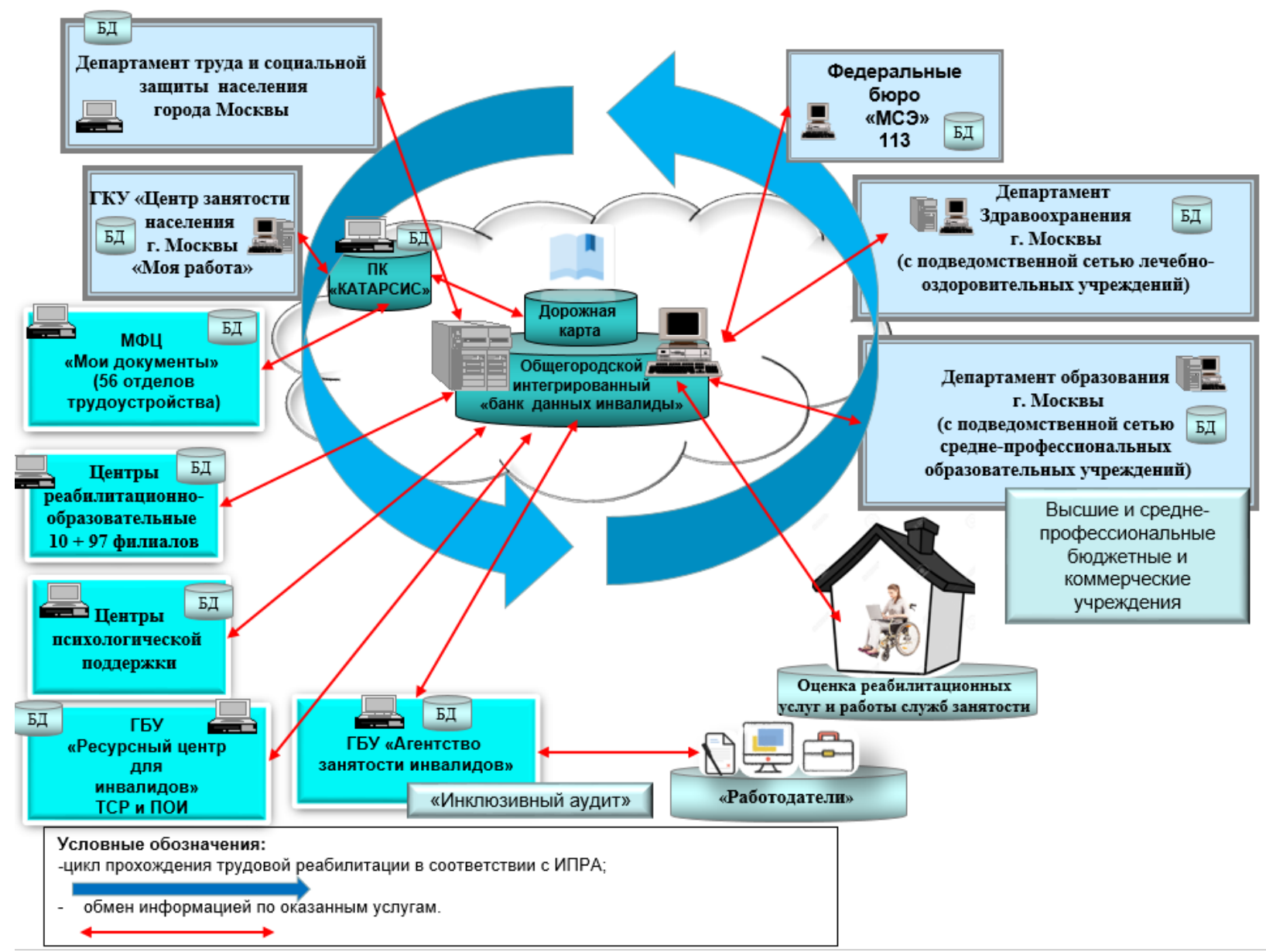

Puc. 3. Схема сопровождения трудовой реабилитации инвалида на базе «Персональной интерактивной дорожной карты занятости инвалида» Источник: Разработано автором 
литационные учреждения здравоохранения и социальной защиты населения; учреждения образования, занимающиеся вопросами профессиональной подготовки и переподготовки инвалидов; учреждения, предоставляющие инвалидам технические средства реабилитации и протезно-ортопедические изделия; всех работодателей, предоставивших рабочие места для инвалидов; общественные организации, представляющие интересы инвалидов в Москве [17].

Что касается обеспечения занятости инвалидов, то для развития рынка труда для них, следует перейти на новый уровень взаимодействия в государственно-частном партнерстве, модификации использования различных форм экономического, организационного сотрудничества, включая возможности социального предпринимательства, а одним из условий предоставления государственных заказов среднему и малому бизнесу может стать создания рабочих мест для инвалидов.

В современной действительности службы занятости получают информацию о наличии вакансий в одностороннем порядке - по добровольной информации работодателя. Автором предлагается введение нового формата взаимодействия с работодателями и контроля в виде «инклюзивного аудита».

В авторской формулировке - «Инклюзивный аудит - деятельность по выявлению среди штатных расписаний организаций (предприятий) рабочих мест для трудоустройства инвалидов (помимо квотируемых) с целью дальнейшего развития рынка труда для них, включая гибкие формы занятости»*.

Организацию и проведение «инклюзивного аудита» целесообразно поручить Агентству занятости инвалидов. При этом инклюзивные аудиты можно проводить как в электронном виде, так и специалистами служб занятости. Организовывать проведение аудита следует с организаций со штатной численностью от 100 человек и более, и прошедших проверку на отсутствие кредитных, зарплатных и иных задолженностей. Информация об имеющихся вакантных местах в организациях, прошедших аудит, должна выгружаться в программный комплекс «Катарсис» для дальнейшего сотрудничества с работодателями и пополнения банка вакансий. В настоящее время программный комплекс «Катарсис» предо- ставляет платформу для электронного взаимодействия служб занятости России с гражданами и работодателя.**

Функции работодателей во взаимодействии с программным комплексом «Катарсис», автор предлагает осуществлять в формате ежедневной передачи данных о наличии вакантных должностей, заработка по ним и профессионально-квалификационных требованиях. Интерактивное взаимодействие позволит контролировать статус отдельных рабочих мест в рамках «Инклюзивного аудита». Предполагается, что «Инклюзивный аудит» будет использоваться (при необходимости) на завершающим этапе реализации «дорожной карты занятости инвалида».

Систему интерактивной связи можно так же использовать для оценки работы служб занятости, работодателями и инвалидами.

В штатной структуре служб занятости, например, в г. Москве имеются специалисты по профориентации, помогающие безработным в предпочтительном выборе профессии для последующего трудоустройства. Помочь в подборе нужной профессии помогла бы разработанная автором формула определения показателя профессиональной компетенции инвалида (ППКИ). Формула базируется на поэтапном выявлении и оценки компетенции неработающих инвалидов в разрезе требований работодателя (см. табл. 1) и структурных компонент человеческого потенциала, направленных на выполнение профессиональных задач.

К компетенциям, формирующимся в результате использования:

- физиологического потенциала, относятся: образование, функциональная грамотность, практические навыки;

- интеллектуального потенциала, относятся: квалификация, инновационность, когнитивные учения и навыки, теоретические знания, прикладные знания;

- мотивационного потенциала, относятся: коммуникационные умения, самостоятельность и автономия.

Для каждого элемента дается оценка по шкале от 0 до 10 баллов:

- от 0 до 3 - слабое проявление компетенции;

- от 4 до 7 - компетенция проявляется на среднем уровне;

\footnotetext{
* Разработано автором

*** Программный комплекс использующийся в системе занятости населения России
} 
- от 8 до 10 - компетенция проявляется на высоком уровне.

Далее с учетом значимости каждой компетенции (см. табл. 2) по соответствующей нозологической группе, рассчитывается общий показатель профессиональной компетенции инвалида (фор. 1)

пПки $=\left(\sum_{i=1}^{3} \alpha \times \kappa_{\phi}+\sum_{i=1}^{5} \beta \times \kappa_{\mathrm{u}}+\sum_{\mathrm{i}=1}^{2} \gamma \times \kappa_{\mathrm{M}}\right)$

где ППКИ - интегральный показатель использования компетенций инвалида, раскрывающих их человеческий потенциал; $\mathrm{K}_{\phi}$ - компетенции, формирующиеся в результате использования физиологического потен- циала; $\mathrm{K}_{\text {И }}$ - компетенции, формирующиеся в результате использования интеллектуального потенциала; $\mathrm{K}_{\mathrm{M}}$ - компетенции, формирующиеся в результате использования мотивационного потенциала; $\alpha, \beta, \gamma$ - весовые коэффициенты соответствующих групп компетенций.

Интервалы уровней в показателях компетенций:

- ППКИ = от 65 до $100-$ высокий уровень профессиональных компетенций и человеческого потенциала;

- ППКИ = от 34 до $64-$ средний уровень профессиональных компетенций и человеческого потенциала;

- ППКИ = от 0 до $33-$ низкий уровень профессиональных компетенций и человеческого потенциала.

Таблица 2. Значимость компетенций компонент человеческого потенциала инвалидов по соответствующей нозологической группе

\begin{tabular}{|c|c|c|c|c|c|c|c|c|}
\hline \multirow{9}{*}{ 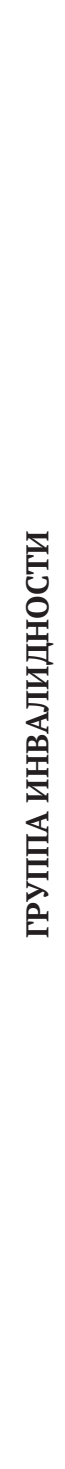 } & & 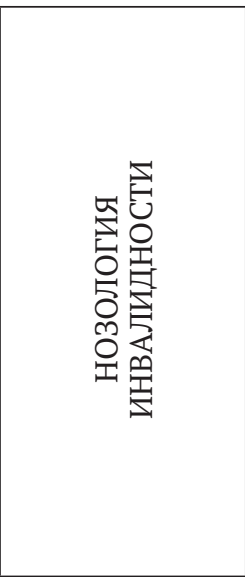 & 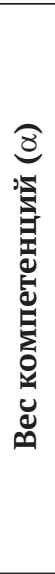 & $\begin{array}{c}\text { Компетенции, } \\
\text { формирующие- } \\
\text { ся в результате } \\
\text { использования } \\
\text { физиологиче- } \\
\text { ского потенци- } \\
\text { ала } \\
\text { K }_{\mathbf{\phi}} \\
\text { • образование } \\
\text { • функциональ- } \\
\text { ная грамотность } \\
\text { • практические } \\
\text { навыки }\end{array}$ & 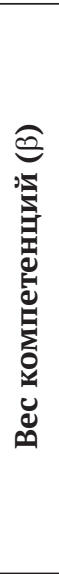 & 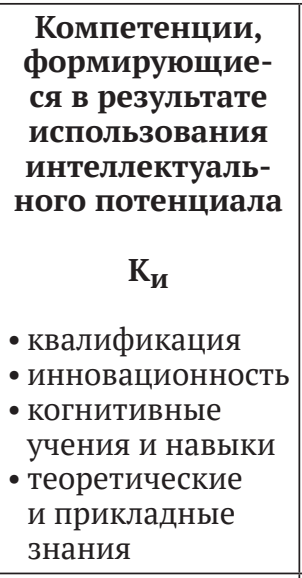 & 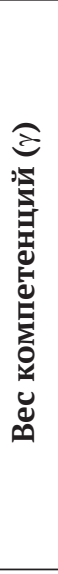 & $\begin{array}{l}\text { Компетенции, } \\
\text { формирующие- } \\
\text { ся в результате } \\
\text { использования } \\
\text { мотивационного } \\
\text { потенциала } \\
\qquad \text { K }_{\mathrm{M}} \\
\text { • коммуникацион- } \\
\text { • ные умения } \\
\text { самостоятель- } \\
\text { • ность } \\
\text { автономия }\end{array}$ \\
\hline & \multirow{4}{*}{$\begin{array}{c}2 \\
\text { группа }\end{array}$} & $\begin{array}{c}\text { Инвалидность } \\
\text { по зрению } \\
\end{array}$ & 3 & \multirow{4}{*}{ от 0 до 10} & 5 & \multirow{4}{*}{ от 0 до 10} & 2 & \multirow{4}{*}{ от 0 до 10} \\
\hline & & $\begin{array}{c}\text { Инвалидность } \\
\text { по слуху }\end{array}$ & 3 & & 5 & & 2 & \\
\hline & & \begin{tabular}{|c|} 
Инвалидность \\
в виду нару- \\
шения опор- \\
но-двигатель- \\
ного аппарата
\end{tabular} & 3 & & 5 & & 2 & \\
\hline & & $\begin{array}{c}\text { Инвалидность } \\
\text { от общих забо- } \\
\text { леваний }\end{array}$ & 3 & & 5 & & 2 & \\
\hline & \multirow{4}{*}{$\begin{array}{c}3 \\
\text { группа }\end{array}$} & $\begin{array}{c}\text { Инвалидность } \\
\text { по зрению }\end{array}$ & 2 & \multirow{4}{*}{ от 0 до 10} & 5 & \multirow{4}{*}{ от 0 до 10} & 3 & \multirow{4}{*}{ от 0 до 10} \\
\hline & & $\begin{array}{c}\text { Инвалидность } \\
\text { по слуху }\end{array}$ & 2 & & 5 & & 3 & \\
\hline & & \begin{tabular}{|c} 
Инвалидность \\
в виду нару- \\
шения опор- \\
но-двигатель- \\
ного аппарата
\end{tabular} & 2 & & 5 & & 3 & \\
\hline & & $\begin{array}{c}\text { Общие заболе- } \\
\text { вания }\end{array}$ & 2 & & 5 & & 3 & \\
\hline
\end{tabular}


На процесс закрепления трудоустроенного инвалида на конкретном рабочем месте влияют различные показатели и критерии, важными из которых являются мотивационно-поведенческие компетенции сотрудника, т.е. «подход к выполнению работы, уровень владения определёнными навыками» [31]. Для их оценки предла- гается, разработанная автором «Матрица оценки мотивационно-поведенческих компетенций сотрудника с инвалидностью» (см. табл. 3). Она необходима для определения и оценки важнейших компетенций инвалида, проработавшего определенный срок в конкретной должности и понимания готов ли, сотрудник продолжить ра-

Таблица 3. Матрица оценки мотивационно-поведенческих компетенций сотрудника с инвалидностью

\begin{tabular}{|c|c|c|}
\hline Уровень компетенции & Поведенческие индикаторы & $\begin{array}{l}\text { Бальная оценка } \\
\text { (от } 1 \text { до 5) }\end{array}$ \\
\hline 1 & 2 & 3 \\
\hline \multirow{2}{*}{$\begin{array}{c}\frac{\text { Уровень } 1}{\text { Стремится выполнять работу }} \\
\text { лучше }\end{array}$} & $\begin{array}{c}\text { Демонстрирует стремление выпол- } \\
\text { нять работу лучше }\end{array}$ & - \\
\hline & $\begin{array}{c}\text { Выражает сожаления о неэффек- } \\
\text { тивно потраченном времени }\end{array}$ & - \\
\hline \multirow{3}{*}{$\begin{array}{c}\frac{\text { Уровень 2 }}{\text { Стремится соответствовать }} \\
\text { стандартам, установленным } \\
\text { руководством }\end{array}$} & $\begin{array}{c}\text { Предпринимает действия, чтобы } \\
\text { выполнить работу в установлен- } \\
\text { ный срок }\end{array}$ & - \\
\hline & $\begin{array}{c}\text { Предпринимает действия, чтобы } \\
\text { уложиться в } \\
\text { лимит по расходным материалам }\end{array}$ & - \\
\hline & $\begin{array}{c}\text { Предпринимает действия, чтобы } \\
\text { результаты работы соответствова- } \\
\text { ли установленным руководством } \\
\text { ключевым показателям эффектив- } \\
\text { ности }\end{array}$ & - \\
\hline \multirow{2}{*}{$\begin{array}{l}\frac{\text { Уровень } 3}{\text { Работает самостоятельно над }} \\
\text { повышением эффективности }\end{array}$} & $\begin{array}{c}\text { Устанавливает собственные пока- } \\
\text { затели эффективности, превышаю- } \\
\text { щие заданные руководством } \\
\end{array}$ & - \\
\hline & $\begin{array}{c}\text { Предпринимает действия по до- } \\
\text { стижению более высоких отно- } \\
\text { сительно заданных показателей } \\
\text { эффективности } \\
\end{array}$ & - \\
\hline \multirow{2}{*}{$\begin{array}{c}\text { Ставит амбициозные, но дости- } \\
\text { жимые цели }\end{array}$} & $\begin{array}{c}\text { Ставит перед собой и руковод- } \\
\text { ством амбициозные, но достижи- } \\
\text { мые цели } \\
\end{array}$ & - \\
\hline & $\begin{array}{c}\text { Предпринимает действия, чтобы } \\
\text { достичь этих целей } \\
\end{array}$ & - \\
\hline \multirow{3}{*}{$\underset{\text { Идет на предпринимательские }}{\frac{\text { Уровень } 5}{\text { риски }}}$} & \begin{tabular}{|c|} 
Идет на обдуманные просчитан- \\
ные риски ради достижения целей
\end{tabular} & - \\
\hline & $\begin{array}{c}\text { Инвестирует ресурсы и время в } \\
\text { исследование и апробирование } \\
\text { новых методов работы, которые } \\
\text { помогут достичь значительно- } \\
\text { го повышения эффективности в } \\
\text { будущем } \\
\end{array}$ & - \\
\hline & $\begin{array}{c}\text { Оценивает и поддерживает пред- } \\
\text { принимательские риски своих } \\
\text { подчиненных }\end{array}$ & - \\
\hline Негативные индикаторы & $\begin{array}{c}\text { Демонстрирует отсутствие интере- } \\
\text { са к работе. Делает только то, что } \\
\text { требуется. Легко «снижает планку», } \\
\text { жертвуя стандартами качества, не } \\
\text { укладывается в сроки. Жалуется на } \\
\text { большой объем работ. Предпочита- } \\
\text { ет выполнять задачи наименьшей } \\
\text { сложности. } \\
\end{array}$ & - \\
\hline Итого: & & - \\
\hline
\end{tabular}

Источник: Разработано автором 
боту в данной должности, профессии или с набором имеющихся компетенций он может претендовать на другие высокооплачиваемые работы. Возможен и негативный вариант - увольнение.

В первой графе матрицы предложено предусмотреть 5 уровней, включающих самые необходимые компетенции для конкретной должности с учетом специфики сотрудника с ограниченными возможностями здоровья. Уровни следует располагать в порядке развития компетенций за время работы, со стремлением к самосовершенствованию. Во второй графе отражаются эмоционально-поведенческие отношения сотрудника к выполняемой работе. Это очень важный момент, так как исходя из четкости и конкретности внесенных формулировок, будет оцениваться сотрудник с инвалидностью, в т.ч. с принятием по нему кадровых решений. Переход на новый уровень связан с качественными изменениями в работе. В третьей графе предусмотрена бальная система оценок относительно каждого поведенческого индикатора. В зависимости от видов труда количество уровней развития компетенций может быть расширено, но при этом соблюдена четкая качественная разница между каждым уровнем и каждой компетенции. В негативном индикаторе суммируется число недополученных до максимума балов.

Целесообразно, чтобы оценку работы инвалида осуществлял его руководитель по прошествии определённого временного интервала работы, на занимаемой должности. Оценку также может произвести трудовой куратор. В зависимости от группы инвалидности, предлагается установить следующие временные параметры, с момента начала работы в оцениваемой должности, для: III-й группы - через 3 месяца; I-й и II-й группы - через 4 месяца.

Состав и перечень компетенций «Матрицы» должно быть согласовано с руководителем подразделения, в котором трудится инвалид, это позволит отражать наличие и соответствие необходимого состава компетенций: либо для продолжения трудовой деятельности по выполняемой работе, либо для принятия решения об его перепрофилировании. Предлагается определять коэффициент компетенций по формулам разработанным автором (фор. 2 и 3).

$$
\begin{aligned}
& \frac{\sum \mathrm{PW}}{\sum \mathrm{MS}}=\mathrm{P}_{\mathrm{cr}} \\
& \frac{\sum \mathrm{NW}}{\sum \mathrm{MS}}=\mathrm{N}_{\mathrm{cr}}
\end{aligned}
$$

Условные обозначения:

- Максимально возможная сумма балов (maximum score) - MS;

- Сумма положительных балов (positive work) - PW;

- Сумма негативных балов (negative work) NW;

- Коэффициент положительных компетенций (positive competencies ratio) $-\mathrm{P}_{\mathrm{cr}}$;

- Коэффициент отрицательных компетенций (negative competence ratio) $-\mathrm{N}_{\mathrm{cr}}$.

Любые отрицательные факторы влияют на конечный результат, следовательно, необходимы соответствующие меры для их устранения. Для стабильной работы лиц с инвалидностью, приемлемым, по нашему мнению, будет уровень коэффициента отрицательной работы не выше «0,35». Шкала коэффициентов по оценке уровня компетенций приведена в таблице (см. табл. 4).

Условные обозначения:

- «Отлично» - полностью мотивирован, осознает цель и задачи работы, использует все ресурсы для достижения максимальных резуль-

\begin{tabular}{|c|c|c|c|c|}
\hline $\begin{array}{c}\text { Показатель суммы } \\
\text { положительных } \\
\text { компетенций }\end{array}$ & $\begin{array}{c}\text { Состояние коэф- } \\
\text { фициента }\end{array}$ & $\begin{array}{c}\text { Диапазон коэф- } \\
\text { фициента по- } \\
\text { ложительной/ } \\
\text { отрицательной } \\
\text { компетенции }\end{array}$ & $\begin{array}{c}\text { Состояние коэф- } \\
\text { фициента }\end{array}$ & $\begin{array}{c}\text { Показатель суммы } \\
\text { отрицательных } \\
\text { компетенций }\end{array}$ \\
\hline Отлично & & $0,76-1$ & & $\begin{array}{c}\text { Не удовлетвори- } \\
\text { тельно }\end{array}$ \\
\hline Хорошо & 0,64 & $0,51-0,75$ & & Удовлетворительно \\
\hline Удовлетворительно & & $0,26-0,5$ & 0,35 & Хорошо \\
\hline $\begin{array}{l}\text { Не удовлетвори- } \\
\text { тельно }\end{array}$ & & $0,1-0,25$ & & Отлично \\
\hline
\end{tabular}

Таблица 4. Шкала коэффициентов по оценке уровня компетенций работающего инвалида

Источник: Разработано автором 
татов, все показатели работы выполняются в срок.

- «Хорошо» - мотивирован, присутствуют незначительные сбои (накладки) в деятельности, однако, все установленные показатели работы выполняются.

- «Удовлетворительно» - слабо мотивирован, имеет место незначительное отставание от нормативов выполнения установленных показателей и снижению результатов работы.

- «Не удовлетворительно» - полное отсутствие мотивации и желания работы, значительное отставание от нормативов, установленных в организации.

Было бы рационально, чтобы работодатель копию «матрицы» направлял в соответствующую службу занятости. Полученная информация, может быть использована для более эффективного трудоустройства инвалида в случае его повторного обращения в службы занятости.

Кроме того, для оценки социально-эконмической эффективности работы по трудовой реабилитации инвалидов, затрат на инвестиции по восстановлению их человеческого капитала можно было бы не реже одного раза в год проводить качественное и количественное измерение по следующим направлениям:

- изменение количества рабочих мест для инвалидов;

- изменение потребностей рынка труда;

- изменение возрастной и качественной структуры среди инвалидов;

- изменение динамики инвалидизации по группам инвалидности среди трудоспособного возраста по группам инвалидности.

Оценка социальной эффективности программ реабилитации/абилитации, обучения и трудоустройства инвалидов может осуществляться по следующей формуле (фор. 4):

$$
\mathrm{C} \ni=\frac{\text { Д }}{3}
$$

где СЭ - социальная эффективность программ, Д - доходы, получаемые лицами с ограниченными возможностями здоровья (сумма заработной платы за год), 3 - бюджетные затра- ты на реабилитацию, обучение и трудоустройство инвалидов в течении предыдущего года.

Подводя итог вышесказанному, к сожалению, приходится констатировать, что на данном этапе вопросы состояния трудовой реабилитации инвалидов, использование их человеческого капитала имеют много проблем и как следствие занятость инвалидов, имеющих трудовые рекомендации в различных регионах не достигает и 50\%, а чаще значительно ниже этого показателя. В качестве механизмов, способствующих повышению занятости инвалидов на российском рынке труда, автором предложено:

1) разработать государственный стандарт услуг по трудовой реабилитации инвалидов в трудоспособном возрасте по нозологии заболеваний.

2) правовое закрепление понятия «трудовая реабилитация» с включением всего комплекса реабилитационных мероприятий с уточнением его компонентов как механизма формирования человеческого капитала инвалидов.

3) организационно-административные мероприятия в виде пилотных проектов:

- по созданию государственного учреждения «Агентства занятости инвалидов»;

- введения «Персональной интерактивной дорожной карты занятости инвалида»;

- новый формата взаимодействия с работодателями - «инклюзивного аудита».

4) разработаны матрицы:

- оценки соответствия элементов профессиональной компетенции инвалида к требованиям вакантной должности;

- оценки мотивационного-поведенческой компетенции сотрудника с инвалидностью.

5) разработаны и составлены формулы:

- интегрального показателя использования компетенций инвалида, раскрывающих их человеческий потенциал;

- коэффициентов компетенций работающего инвалида;

- оценки социальной-экономической эффективности программ реабилитации/абилитации, обучения и трудоустройства.

\section{Библиографический список}

1. Актуальные проблемы трудоустройства инвалидов в городе Москве // Социальная работа сегодня: вектор развития: Сборник научных статей аспирантов / Под. ред. И.В. Мкртумовой, Н.В. Лебедевой.- М.: ИДПО ДТСЗН, 2016.- С.59.; 
2. Беккер Г. С. Теория распределения времени // Вехи экономической жизни. Рынки факторов производства. Т.3 Под ред. В.М. Гальперина.- СПб.: Экономическая школа, 2000;

3. Беккер Г. Экономический взгляд на жизнь. Лекция лауреата Нобелевской премии в области экономических наук за 1992 г./ Вестник С.-Петербургского университета, серия 5., вып.3, 1993.;

4. Бардина И.В., Землянухина С.Г. Рынок интеллектуального труда в инновационной экономике России // Вестник СГТУ. 2010. № 1. URL: https://cyberleninka.ru/article/n/rynok-intellektualnogo-truda-v-innovatsionnoyekonomike-rossii (дата обращения: 09.07.2019).;

5. Большой экономический словарь./ Под ред. А.Н. Азрилияна.-М.: Фонд «Правовая культура», 1994., с.470.;

6. ГОСТ Р 54738-2011 «Реабилитация инвалидов. Услуги по социальной реабилитации инвалидов» (дата введение 01-04-2013) [Текст] [Электронный ресурс] // Электронной фонд правовой и нормативно-технической документации. URL: http://docs.cntd.ru/document/1200093162 (09.07.2019);

7. Дмитриев М.Э., Никольская А.В. О возможности внедрения эффективной методики трудоустройства инвалидов на базе центров занятости населения. [Статья] [Электронный ресурс] // Режим доступа - http:// synergy-journal.ru/archive/article1610 (дата обращения 10.07.2019);

8. Доклад о положении инвалидов в городе Москве / Департамент труда и социальной защиты населения города Москвы, Институт дополнительного профессионального образования работников социальной сферы; под общей редакцией В.А. Петросяна, Е.И. Холостовой.- М.: 2016.-С. 54-70;

9. Доклад к отчету о выполнении государственных программ города Москвы «Социальная поддержка жителей города Москвы» за 2018 год. [Текст]: PDF - 2019.- (https://dszn.ru/uploads/magic/ru-RU/Document-01315-src-1554795517.9748.pdf).;

10. Золоторева Евгения., В России высокий уровень человеческого капитала // «Экономика и жизнь» № 5 (9771) 2019. URL: https://www.eg-online.ru/article/393518/ (дата обращения 09.07.2019);

11. Изучении процессов интеграции инвалидов города Москвы в общество и выявления основных факторов, влияющих на этот процесс: информационно-аналитический отчет - М., 2016,- С.22-29;

12. Конституция Российской Федерации [Электронный ресурс]: принята всенародным голосование 12 декабря 1993 года.: (с учетом поправок, внесенных Законами Российской Федерации о поправках к Конституции Российской Федерации от 30.12.2008 № 6-ФК3, от 30.12.2008 N7-ФК3, от 05.02.2014 N2-ФК3, от 21.07.2014 № 11-ФК330 декабря 2008 № 6-ФКЗ и № 8-ФКЗ) // СПС «Консультант плюс».- Режим доступа: http://www. consultant.ru/ (дата обращения 01.05.2019);

13. Конвенция о правах инвалидов, 2006 г., ст. 27 «Труд и занятость» [Электронный ресурс]: PDF // Режим доступа - http://ombudsmanspb.ru/files/files/OON_02_site.pdf.;

14. Комплексный мониторинг уровня и качества жизни инвалидов в городе Москве: информационно-аналитический доклад. II этап / под общей редакцией В.А. Петросяна, Е.И. Холостовой.- М.: ГАУ ИДПО ДТСЗН, 2017.- С. 22-47.;

15. Капелюшников Р.И. Концепция человеческого капитала // Критика современной буржуазной политической экономии.-М.: Наука, 1977;

16. Капелюшников, Р.И.Экономические очерки: Методология, институты, человеческий капитал [Текст] / Р.И. Капелюшников; Нац. исслед. ун-т «Высшая школа экономики».- М.: Изд. дом Вышей школы экономики, 2016.- С. 51-59.;

17. Леонтьева Л.С., Орлова Л.Н. Управление интеллектуальным капиталом.- М.: Юрайт, 2016. - 295 с.;

18. На «Форуме труда» в Петербурге обсудят рост экономики на основе человеческого капитала. Источник: TACC. URL: https://tass.ru/ekonomika/6167587 (дата обращения 10.07.2019);

19. Послание Президента РФ Федеральному собранию 1 декабря 2016 года. Сайт Президента России. URL: http://kremlin.ru/events/president/news/53379 (дата обращения 08.07.2019)

20. Постановление Правительства Российской Федерации от 20 февраля 2006 года № 95 «О порядке и условиях признания лица инвалидом» (с изменениями на 27 июня 2019 года) // [Электронный ресурс] Электронный фонд правовой и нормативно-технической документации. URL: http://docs.cntd.ru/document/901969284 (дата обращения 09.07.2019);

21. Проект развития человеческого капитала. Всемирный банк MБPP. URL: https://www.vsemirnyjbank.org/ru/ publication/human-capital (дата обращения 09.07.2019);

22. Реабилитация инвалидов / Л.П. Храпылина, М.: Издательство «Экзамен», 2006.- С.155;

23. Статистика Росстата о положении инвалидов: труд и занятость. [Электронный ресурс] - 2019.- http:// www.gks.ru/wps/wcm/connect/rosstat_main/rosstat/ru/statistics/population/disabilities/ (дата обращения 30.04.2019); 
24. Федеральный закон от 1 декабря 2014 г. № 419-Ф3 «О внесении изменений в отдельные законодательные акты Российской Федерации по вопросам социальной защиты инвалидов в связи с ратификацией Конвенции о правах инвалидов» (с изменениями и дополнениями от 29 декабря 2015 г.) - [Электронный ресурс]: ГАРАНТ // Режим доступа - http://base.garant.ru/70809036/\#ixzz52Cbpnin9 (дата посещения 30.03.2019);

25. Федеральный закон от 19.04.1991 № 1032-1 (ред. от 11.12.2018) «О занятости населения в Российской Федерации» (с изм. и доп., вступ. в силу с 01.01.2019) - [Электронный ресурс]: КонсультантПлюс // URL: http:// www.consultant.ru/document/cons_doc_LAW_60/70c0a8cdc34b8e2d7e7ef698488d51acc556dc7e/ (дата обращения 26.04.2019 г.);

26. Федеральный закон от 24.11.1995 № 181-ФЗ (ред. от 29.07.2018) «О социальной защите инвалидов в Российской Федерации» (с изм. и доп., вступ. в силу с 01.01.2019) [принят ФС РФ 15 ноября 1995] // [Электронный ресурс] КонсультантПлюс. URL: http://www.consultant.ru/document/cons_doc_LAW_8559/.;

27. Федеральный реестр инвалидов. [Электронный ресурс] - 2019. Режим доступа - https://sfri.ru/analitika/ zanyatost/zanyatost?territory=1 (дата обращения 01.05.2019);

28. Фадин Н.И., Шубенкова Е.В. Развитие механизма повышения занятости и конкурентоспособности инвалидов (на примере города Москвы). // Экономические науки. 2018. № 161. С. 42-50.;

29. Шубенкова Е.В., Войкина Е.А., Куксова О.Д. Российский опыт реализации образовательных программ в сфере социального предпринимательства // Вестник Саратовского государственного социально-экономического университета, 2017. - № 5 (69).- С. 165-168.

30. Хайникин M.M., Эволюция теории человеческого капитала // Российская национальная библиотека, 2017. URL: http://nlr.ru/news/20170427/haikin.pdf (дата обращения 10.07.2019);

31. Оценка персонала. Критика теории и практики применения системы сбалансированных показателей / В.Е. Хруцкий, Р.А. Толмачев.-2-е изд., перераб. и доп.-М.: Финансы и статистика, 2009.- С. 58-59.;

32. Schulz T. Investment in Human Capital // American Economic Revien. - 1961, March — № 1.;

33. Schultz, Theodor W. Investment in human capital: the role of education and research. N.Y., 1971.;

34. Schulz T. Capital Formation bi Edukathion // Journal of Politikal Economu. - 1960, p.25.;

35. Becker G.S. Investment in Human Capital: A. Theoretical Analysis // Journal of Politikal Economy. Supplement. Oct., 1962.;

36. Becker G.S. Human capital: A Theoretical and Empirical Analysis with Special Reference to Education. Third edition. Chicago. The University of Chicago Press, 1993. 